Skinner DG, Lieskovsy G, eds. Diagnosis and munagement of geniourinury cancer. Philadelphia: WB Saunders, 1988:32-9.

12 Boston Collaborative Drug Surveillance Group. Regular aspirin intake and acute myocardial infarction. Br Med 7 1974; i: $440-3$.

13 Elwood PC, Cochrane AL, Burr ML, et al. A randomized controlled trial of aceryl salicylic acid in the secondary prevention of mortality from myocardial infarction. Br Med f 1974; ; : 436-40.

14 Coronary Drug Project Research Group. Aspirin in coronary heart disease. f Chronic Dis 1978;29:625-42.

15 Aspirin Myocardial Infarction Study Research Group. A randomized, controlled trial of aspirin in persons recovered from myocardial infarction. JAMA 1980;243:661-9.

16 Antiplatelet Trialists' Collaboration. Secondary prevention of vascular disease by prolonged antiplatelet treatment. $\mathrm{Br}$ Med $\mathcal{F}$ 1988;296:320-31.

17 Young FE, Nightingale, Temple RA. The preliminary report of the finding of the aspirin component of the ongoing Physicians' Health Study. The FDA perspective on aspirin for the primary prevention of myocardial infarction. ҰAMA 1988;259:3158-60.

18 Peto R, Gray R, Collins R, et al. A randomised trial of the effects of prophylactic daily aspirin among male British doctors. Br Med f 1988;296: 313-6.

19 Belcon MC, Rooney PJ, Tugwell P. Aspirin and gastrointestinal haemorrhage: a methodologic assessment. I Chronic Dis 1985;38:101-11.

20 Piper DW, McIntosh JH, Aritotti DE, Fenton BH, MacLennan R. Analgesic ingestion and chronic peptic ulcer. Gastroenterology 1981;80:427-32.
21 McIntosh JH, Byth R, Piper DW. Environmental factors in aetiology of chronic gastric ulcer: a case control study of exposure variables before the first symptoms. Gut 1985;26:789-98.

22 Faulkner G, Prichard P, Somerville K, Langman MJS. Aspirin and bleeding peptic ulcers in the elderly. Br Med $\mathcal{F} 1988 ; 297: 1311-3$.

23 Cotlier $\mathrm{E}$. Aspirin and senile cataract in rheumatoid arthritis. Lancel $1981 ; i: 338-9$.

24 Cotlier E. Senile cataracts: evidence for acceleration by diabetes and deceleration by salicylate. Can 7 Ophthalmol 1981;16:113-8.

25 Van Heyningen R, Harding JJ. Do aspirin-like analgesics protect agains cataract? Lancet $1986 ; \mathrm{i}: 1111-3$.

26 Cotlier E. Rheumatoid arthritis and cataract surgery. Int Ophthalmol 1980;2 127-9.

27 Seigel D, Sperduto RD, Ferris FL III. Aspirin and cataracts. Ophthalmology 1982;89:47-8A.

28 West SK, Munoz BE, Newland HS, Emmett EA, Taylor HR. Lack of evidence for aspirin use and prevention of cataracts. Arch Ophthalmol 1987;105:1229-31.

29 Kewitz H, Nitz M, Gaus V. Aspirin and cataract. Lancet 1986;ii:689.

30 Paganini-Hill A, Ross RK. Reliability of recall of drug usage and other health related information. Am $\mathcal{F}$ Epidemiol 1982;116:114-22.

(Accepted 15 September 1989)

\title{
Perinatal transmission of HIV-I in Zambia
}

\author{
S K Hira, J Kamanga, G J Bhat, C Mwale, G Tembo, N Luo, P L Perine
}

Dermato-Venereology Department, University Teaching Hospital, Box 50001, Lusaka, Zambia S K Hira, MD, consultant J Kamanga, DCMS, clinical officer

C Mwale, DCMS, clinical officer

Department of Paediatrics, University Teaching

Hospital, Lusaka

G J Bhat, MD, senior lecturer

Department of Community Medicine, University

Teaching Hospital, Lusaka

G Tembo, MPH, lecturer

Department of Pathology/ Immunology, University

Teaching Hospital, Lusaka

N Luo, PHD, lecturer

Uniformed Services

University of the Health

Sciences, Bethesda,

Maryland, United States

$\mathrm{PL}$ Perine, MPH, professor of

tropical public health

Correspondence to:

Dr Hira.

BrMed F 1989;299:1250-2

\section{Abstract}

Objective-To determine the occurrence of vertical transmission of HIV-I from women positive for the virus and the prognosis for their babies.

Design-Women presenting in labour were tested for HIV-I. Their newborn babies were also tested. Women positive for the virus were followed up with their babies for two years.

Setting-Teaching hospital in Lusaka, Zambia.

Subjects - 1954 Women, of whom 227 were seropositive. Of 205 babies, 192 were positive for HIV-I. After birth 109 seropositive mothers and their babies and $\mathbf{4 0}$ seronegative mothers and their babies were available for follow up.

Main outcome measures-Serological examination of mothers and their babies by western blotting. Birth weight and subsequent survival of babies. Women and babies were tested over two years for signs of seroconversion and symptoms of infection with HIV, AIDS related complex, and AIDS.

Results - Of the 109 babies born to seropositive mothers and available for follow up, 18 died before 8 months, 14 with clinical AIDS. Of the 91 remaining, 23 were seropositive at 8 months. By 24 months 23 of 86 surviving babies were seropositive, and a further five infected babies had died, four were terminally ill, 17 had AIDS related complex, and two had no symptoms. The overall rate of perinatal transmission was 42 out of $109(39 \%)$. The overall mortality of infected children at 2 years was 19 out of $42(44 \%)$. Before the age of 1 year infected children had pneumonia and recurrent coughs, thereafter symptoms included failure to thrive, recurrent diarrhoea and fever, pneumonia, candidiasis, and lymphodenopathy. All babies had received live attenuated vaccines before 8 months with no adverse affects.

Conclusions - Vertical transmission from infected mothers to their babies is high in Zambia and prognosis is poor for the babies. Perinatal transmission and paediatric AIDS must be reduced, possibly by screening young women and counselling those positive for HIV-I against future pregnancy.

\section{Introduction}

HIV-I may be transmitted from an infected mother to her fetus during pregnancy or childbirth. ${ }^{1-4}$ Various studies estimate that about $20-50 \%$ of infants born of infected mothers are also infected. ${ }^{56}$ We studied the incidence of vertical transmission of HIV-I in Lusaka, Zambia, and the possible risks of immunising potentially infected infants with attenuated vaccines.

\section{Patients and methods}

During February to May 1987, 1954 consecutive women delivering at this hospital were entered in the study. We obtained detailed histories after getting informed consent and performed a thorough physical examination and collected $3-5 \mathrm{ml}$ venous blood. Cord blood was taken from live and stillborn infants. The serum samples of mother, baby, and, in some cases, the father were tested for antibodies to HIV-I by enzyme linked immunosorbent assay (ELISA) and western blot analysis. We attempted to trace and follow up two groups: (a) all women positive for antibody to HIV-I and their infants and (b) 40 sets of women negative for antibody to HIV-I and their infants. All seropositive women and their spouses were counselled. Repeat venous blood samples were collected from mothers and infants in both the groups at 6-8, 12, 18, and 24 months and tested for antibodies to HIV and a complete blood count was done. All children received vaccines: BCG at birth, oral polio and diphtheria, pertussis, and tetanus at 3,4 , and 5 months, and measles at 8 months.

Data were analysed by using $\chi^{2}$ tests with epidemiologic software from the Centers for Disease Control.

\section{Results}

Of 1954 women screened at delivery, $227(12 \%)$ were seropositive for HIV-I. The seropositive women were significantly younger with a mean (SD) age of 23.9 $(5.4)$ years (Student's $t$ test $p<0 \cdot 05)$. The seronegative women had a mean (SD) age of $25 \cdot 1(7 \cdot 7)$ years. Among seropositive women, $62(27 \%)$ were primigravidas and $185(82 \%)$ were married. Risk cofactors such as higher number of lifetime sexual partners (table I), single or divorced or widowed, higher educational state (table II), history of transfusion, travel abroad, and working (table III) were associated with high seroprevalence of HIV-I. Fifty two $(23 \%)$ of the seropositive women had adverse outcomes compared with $227(13 \%)$ of the seronegative women 
$(\mathrm{p}<0.001)$ (table IV). This difference, however, was due mainly to the high number of low birthweight infants born to seropositive mothers (odds ratio $=3.75$; $95 \%$ confidence interval $2 \cdot 15$ to $6 \cdot 53$ ).

At labour none of the 109 seropositive mothers for whom follow up was possible had AIDS, $17(16 \%)$ had AIDS related complex, $41(38 \%)$ had generalised lymphadenopathy, and the remaining 51 had no symptoms. Subsequently, during two years of follow up, four (4\%) developed AIDS, $30(28 \%)$ had AIDS related complex, $50(46 \%)$ had generalised lymphadenopathy, and the remaining 25 had no symptoms.

Mothers who infected their children (transmitters) tended to be younger (table V). As there was clustering of non-transmitters around the age group 16-30 the age was arbitrarily dichotomised and 34 out of $42(81 \%)$ transmitters were $\leqslant 30$. By comparison nontransmitters were older and only 38 out of $67(57 \%)$

TABLE I - Number of lifetime sexual partners and seroprevalence of $H I V-I$ among women screened at delivery ${ }^{\star}$

\begin{tabular}{ccc}
\hline $\begin{array}{c}\text { No of sexual } \\
\text { partners }\end{array}$ & $\begin{array}{c}\text { No of women } \\
(\mathbf{n}=1899)\end{array}$ & $\begin{array}{c}\text { No (\%) of women } \\
\text { positive for HIV-I } \\
(\mathbf{n}=227)\end{array}$ \\
\hline 1 & 881 & $92(10)$ \\
2 & 479 & $50(10)$ \\
3 & 271 & $39(14)$ \\
4 & 115 & $11(10)$ \\
5 & 72 & $15(21)$ \\
6 & 35 & $8(23)$ \\
7 & 9 & $2(22)$ \\
8 & 8 & $2(25)$ \\
$>10$ & 29 & $8(28)$
\end{tabular}

^Data unknown for 55 women.

TABLE II-Marital state and educational attainment and seroprevalence of $H I V-I$

\begin{tabular}{lcc}
\hline & No of women & $\begin{array}{c}\text { No(\%) of women } \\
\text { positive for HIV-I } \\
(\mathbf{n}=227)\end{array}$ \\
\hline Married & Marital state & \\
Remarried & 1654 & $177(11)$ \\
Never married & 49 & $6(12)$ \\
Divorced & 222 & $39(18)$ \\
Widowed & 21 & $4(19)$ \\
& 4 & $1(25)$ \\
None & & \\
Primary & 188 & $10(5)$ \\
Secondary & 1122 & $117(10)$ \\
University & 599 & $92(15)$ \\
& 36 & $8(22)$
\end{tabular}

^Data on marital state known for 1950 women and on educational attainment for 1945 women.

TABLE III - Maternal risk cofactors for high seroprevalence of $H I V-I$

\begin{tabular}{lcc}
\hline Risk cofactor & $\begin{array}{c}\text { No (\%) of women } \\
\text { positive for HIV-I } \\
(\mathrm{n}=227)\end{array}$ & $\begin{array}{c}\text { No (\%) of women } \\
\text { negative for HIV-I } \\
(\mathrm{n}=1727)\end{array}$ \\
\hline History of anal sex & $32(14)^{\star}$ & $9(<1)$ \\
Past history of transfusion & $37(16)^{\star \star}$ & $128(7)$ \\
History of travel abroad & $4(2)$ & $169(10)$ \\
Past history of genital ulcers & $41(18)^{\star \star}$ & $220(13)$ \\
Working & & \\
\hline${ }^{\star} \mathrm{p}<0 \cdot 001 . \quad{ }^{\star \star} \mathrm{p}<0 \cdot 002$. & &
\end{tabular}

TABLE IV-Adverse outcomes of pregnancy among HIV-I infected and non-infected women

\begin{tabular}{lcc}
\hline Complications & $\begin{array}{c}\text { No of women } \\
\text { positive for HIV-I } \\
(\mathrm{n}=227)\end{array}$ & $\begin{array}{c}\text { No of women } \\
\text { negative for HIV-I } \\
(\mathrm{n}=1727)\end{array}$ \\
\hline Abortion & 10 & 62 \\
Stillbirth & 5 & 30 \\
Low birth weight & $22^{\star}$ & 48 \\
Preterm or prematurity & 15 & 87 \\
\hline Total & $52(23)$ & $227(13)$ \\
\hline
\end{tabular}

${ }^{\star} \mathrm{p}<0.001 ;$ Odds ratio $=3.75(95 \%$ confidence interval $2 \cdot 15$ to 6.53$)$.
TABLE $\mathrm{v}-$ Association between maternal age of women positive for $H I V-I$ and whether they transmitted HIV-I to their babies

\begin{tabular}{ccc} 
Age (years) & $\begin{array}{c}\text { Nowho transmitted } \\
\text { HIV-I }(\mathbf{n}=\mathbf{4 2})\end{array}$ & $\begin{array}{c}\text { No who did not } \\
\text { transmit HIV-I } \\
(\mathrm{n}=67)\end{array}$ \\
\hline $16-$ & 13 & 10 \\
$21-$ & 15 & 18 \\
$26-$ & 6 & 10 \\
$31-$ & 5 & 22 \\
$>35$ & 3 & 7
\end{tabular}

TABLE VI-Disease profile of women positive for HIV-I at labour and whether they transmitted HIV-I to their babies

\begin{tabular}{lcc}
\hline Stage & $\begin{array}{c}\text { No }(\%) \text { who } \\
\text { transmitted HIV-I } \\
(\mathrm{n}=42)\end{array}$ & $\begin{array}{c}\text { No }(\%) \text { who did not } \\
\text { transmit HIV-I } \\
(\mathrm{n}=67)\end{array}$ \\
\hline AIDS & $10(24)$ & $8(12)$ \\
AIDS related complex & $15(36)$ & $24(36)$ \\
Generalised lymphadenopathy & $17(41)$ & $35(52)$ \\
Seropositive but no symptoms & $18(43)$ & $18(27)$ \\
Progressive illness during & & \\
$\quad$ follow up & &
\end{tabular}

For all variables $\mathrm{p}>0.05$.

mothers who did not infect their children were $\leqslant 30$ $(\mathrm{p}<0.001)$. Among the transmitters there was a trend for them to be more ill at the time of delivery and during the subsequent follow up of two years (table VI).

After we excluded stillbirths 205 specimens of cord blood from infants born to seropositive women were available for testing and $192(94 \%)$ proved positive for antibody to HIV-I. Only 109 out of 205 (53\%) sets of seropositive mothers and children were followed for two years. Of 61 children who became seronegative at 8 months, antibodies to HIV-I reappeared in nine at 12 months (figure). By comparison none of the nine children who became seronegative at 12 months showed a reappearance of antibodies. On the other hand, four out of $22(18 \%)$ children who were seropositive up to 12 months became negative at 18 months and were free of symptoms after 24 months. Hence passively transferred antibodies to HIV-I probably persisted in these children up to 18 months. Interestingly, of 13 neonates who were seronegative at birth, four $(31 \%)$ converted to become seropositive at different ages: two seroconverted by 8 months, one converted between 8 and 12 months, and one between 12 and 19 months.

The important clinical features among the infected children during the first year of life were pneumonia and recurrent cough. During the second year the features were failure to thrive, recurrent diarrhoea, recurrent fever, lymphadenopathy, pneumonia, and candidiasis (table VII).

During the longitudinal follow up of children 18 died before 8 months of age; 14 had clinical features of AIDS $^{7}$ and were seropositive at birth. The remaining four deaths occurred in children who were seronegative at birth; three had gastroenteritis and one had pneumonia. Subsequent follow up showed that by two years another five infected children had died (one, three, and one at 10,16-18, and 23 months, respectively), four were terminally ill (two with miliary tuberculosis), 17 had AIDS related complex, and two had no symptoms. Thus, including 14 children who had died from clinical AIDS before 8 months of age, the rate of perinatal transmission was 42 out of 109 ( $39 \%$; $95 \%$ confidence interval $29 \cdot 4$ to $47 \cdot 6 \%$ ). Also, 40 of $42(95 \% ; 88.8$ to $100 \%)$ infected children developed illness and the mortality was 19 out of $42(44 \% ; 30$ to $60 \%$ ) during the first two years of life. Among children who were persistently seropositive, the mortality at two years was 17 out of $25(68 \%)$. By comparison, a significantly lower mortality of two out of $17(12 \%)$ was 


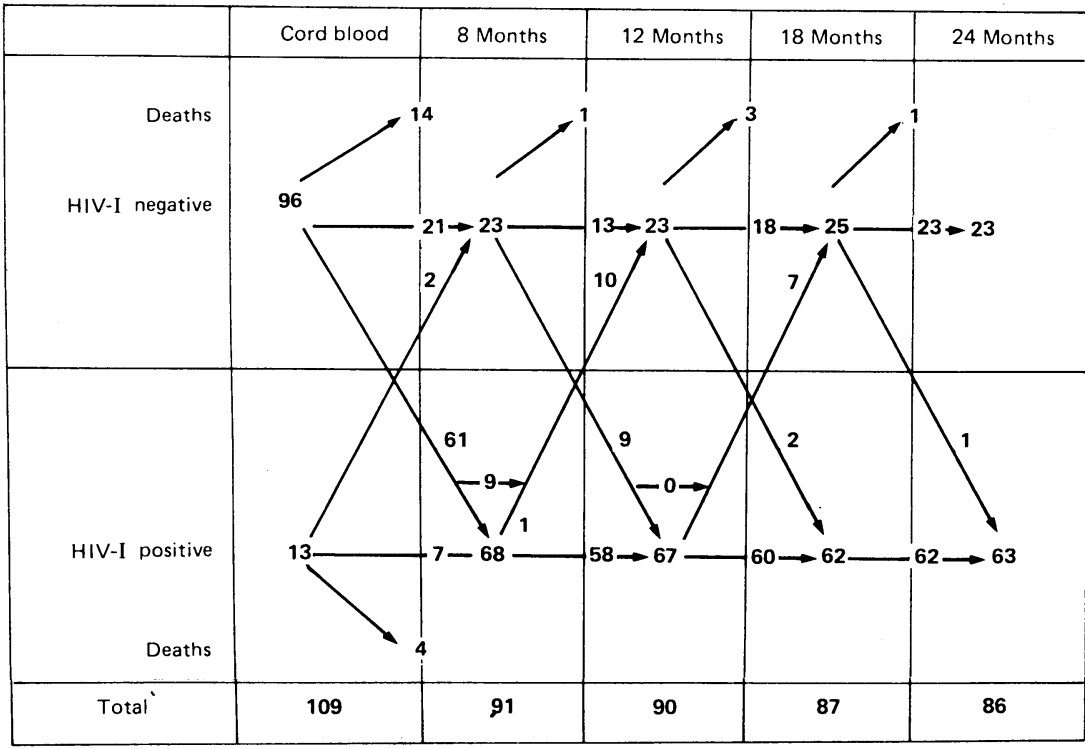

Pattern of HIV-I seroconversion in babies of seropositive mothers during follow up

observed among children whose serology fluctuated $(\mathrm{p}<0.001)$.

BCG adenitis was observed in one of $42(2 \%)$ infected children, three of $67(5 \%)$ children negative for HIV born to seropositive mothers, and three of 40 (8\%) children born to HIV negative mothers. Later, three of $42(7 \%)$ children in the first group developed miliary tuberculosis (relative risk 5.4); one each at 10 , 15 , and 16 months. All had received BCG vaccination at birth. Also, one of 67 (2\%) HIV negative children born to seropositive mothers developed pulmonary tuberculosis at 9 months of age. None of the children born to HIV negative mothers developed tuberculosis. None of the infants developed clinical polio, diphtheria, pertussis, tetanus, or vaccine related measles.

\section{Discussion}

This study documents the high risk of vertical transmission of HIV-I. The significant difference in adverse outcomes of pregnancy between infected and non-infected mothers was primarily related to low birth weight (table IV). The infected mothers were $2 \cdot 9$ times more likely to deliver low birthweight babies. The transmission, disease, and mortality in infected children was higher than that reported in the European collaborative study. ${ }^{8}$ Interestingly, younger women and those with progressive HIV related illness were more effecient transmitters of infection through the perinatal route. One of our important findings was that over two thirds of the children born to seropositive women escaped infection despite being breast fed for 15 to 18 months. Although possible transmission in breast milk has been reported (S Hira, unpublished

TABLE VII - Clinical features in children infected with $H I V-I^{\star}$

\begin{tabular}{|c|c|c|c|c|c|c|c|c|c|c|}
\hline \multirow[b]{3}{*}{ Clinical features } & \multicolumn{2}{|c|}{ First year } & \multicolumn{2}{|c|}{ Second year } & \multirow{2}{*}{\multicolumn{2}{|c|}{$\begin{array}{c}\text { Positive } \\
\text { predictive value }\end{array}$}} & \multirow{2}{*}{\multicolumn{2}{|c|}{ Odds ratio }} & \multirow{2}{*}{\multicolumn{2}{|c|}{$\mathrm{p}$ Value }} \\
\hline & \multirow{2}{*}{$\begin{array}{c}\text { No }(\%) \\
\text { infected } \\
(n=42)\end{array}$} & \multirow{2}{*}{$\begin{array}{c}\text { No }(\%) \\
\text { non- } \\
\text { infected } \\
(n=107)\end{array}$} & \multirow{2}{*}{$\begin{array}{c}\text { No }(\%) \\
\text { infected } \\
(n=25)\end{array}$} & \multirow{2}{*}{$\begin{array}{c}\text { No }(\%) \\
\text { non- } \\
\text { infected } \\
(n=101)\end{array}$} & & & & & & \\
\hline & & & & & $\begin{array}{l}\text { First } \\
\text { year }\end{array}$ & $\begin{array}{l}\text { Second } \\
\text { year }\end{array}$ & $\begin{array}{l}\text { First } \\
\text { year }\end{array}$ & $\begin{array}{l}\text { Second } \\
\text { year }\end{array}$ & $\begin{array}{l}\text { First } \\
\text { year }\end{array}$ & $\begin{array}{l}\text { Second } \\
\text { year }\end{array}$ \\
\hline Failure th thrive & & $23(22)$ & 2 & & 4 & 53 & 2 & 46 & 0.04 & $<0$ \\
\hline Recu & 2 & 35( & $20(80)$ & 20 & 3 & 40 & $2 \cdot 26$ & $9 \cdot 47$ & 0.03 & $<0.001$ \\
\hline $\operatorname{Rec}$ & $18(43)$ & $21(2$ & $17(68)$ & 27( & 47 & 38 & $3 \cdot 26$ & $5 \cdot 82$ & 0.003 & $<0.001$ \\
\hline Recurrent cough & $39(93)$ & $58(54)$ & $25(100)$ & $77(77)$ & 40.6 & $26 \cdot 4$ & $11 \cdot 40$ & $7 \cdot 08$ & $<0.001$ & 0.008 \\
\hline & $23(55)$ & $5(5)$ & $14(56)$ & $3(3)$ & & $82 \cdot 4$ & $31 \cdot 17$ & $41 \cdot 60$ & $<0.001$ & $<0.001$ \\
\hline ulosis & $1(2)$ & $1(1)$ & $2(8)$ & & $50 \cdot 0$ & $100 \cdot 0$ & 2.59 & $t$ & 0.49 & 0.004 \\
\hline Can & & $2(2)$ & $7(28)$ & & $60 \cdot 0$ & 100 & 4.04 & & $0 \cdot 10$ & $<0.001$ \\
\hline enopath & $18(43)$ & $23(22)$ & $17(68)$ & $16(16)$ & 43.9 & 73.9 & $2 \cdot 74$ & $11 \cdot 29$ & 0.008 & $<0.001$ \\
\hline Hepatosplenomegaly & - $12(29)$ & $20(19)$ & & $2(2)$ & 37 & & 1.74 & & $0 \cdot 18$ & $0 \cdot 47$ \\
\hline$B C G$ adenitis & $1(2)$ & $6(6)$ & & & $14 \cdot 3$ & & 0.41 & & $0 \cdot 40$ & \\
\hline
\end{tabular}

^Based on Centers for Disease Control definition.

†Undetermined because of wide variation in values. data), breast milk seems to be an inefficient mode of transmission.

HIV-I serology is unreliable among children under 18 months of life, though seropositive state at 12 months of age in association with specific clinical features is helpful in making a presumptive diagnosis. The pattern of seroconversion (figure) is useful for interpreting serology among children in developing countries, where facilities for polymerase chain reaction and viral isolation tests are not always available. The delayed seroconversion in four children was possibly due to immunological inertia. All these children, however, had clinical features suggestive of immune suppression while they were seronegative. As such, $5-10 \%$ of seronegative children may be infected based on viral culture studies. ${ }^{8}$ We therefore recommend that a child with suggestive clinical features should be tested with the mother for HIV-I. If the mother is seropositive, the child should be followed up for two years. Another interesting phenomenon was a mother who was seronegative at delivery while the cord blood specimen from the infant was seropositive. The mother seroconverted after three months.

Perinatal transmission is directly associated with the stage of HIV-I related illness of the mother (R Ryder, unpublished data). In our study, 58 out of $109(53 \%)$ seropositive mothers had symptoms, which explains the high perinatal transmission rate of $39 \%$. Although a mortality of $44 \%$ during two years of life among infected children was fairly low, possibly due to regular prompt clinical care, the morbidity was enormous. All except two infected children had recurrent episodes of illnesses requiring frequent admissions to hospital.

As reported in other studies ( $\mathrm{J}$ Embree and $M$ Mvula, unpublished data) the HIV-I infected children in our study received live vaccines without any apparent complications. Hence immunisation of infected children should not be discouraged in developing countries until contrary information is available. The $7 \cdot 1 \%$ incidence of tuberculosis over two years among infected children, however, was high. The single case of tuberculosis in a non-infected child born of a seropositive mother possibly represented secondary transmission.

During the follow up two of $42(5 \%)$ mothers who had infected children died from AIDS. The care of infected children by the single parent or grandparents raises a number of social issues. It is, therefore, important to prevent perinatal transmission and occurrence of paediatric AIDS, possibly by screening young women before pregnancy and counselling seropositive patients against future pregnancies.

This study was supported by the International Development Research Centre of Canada; the Ministry of Health, Zambia, and the United States Army Medical Research and Development Command Grant DAMD17-86-MM-6513. We are grateful to Dr D Chikamata, Dr U Mangrola, and Mr R Macuacua of the University Teaching Hospital, Lusaka, for their participation in the study.

1 Chiodo F, Ricchi E, Costigliola P, $t$ t al. Vertical transmission of HTLV-III Lancet 1986:i:739

2 Lapointe N, Michaud J, Pekovic D, et al. Transplacental transmission of HTLV-III virus. N Engl Y Med 1985;312:1325-6.

3 Cowan MJ, Hellmann D, Chudwin D, et al. Maternal transmission of acquired immune-deficiency svndrome. Pediatrics 1984;73:382-6.

4 Ragni MV, Urhach AH, Kiernan S, et al. Acquired immunodeficiency syndrome in a child of a haemophiliac. Lancet 1985;i:133-5.

5 Anonymous. Recommendation for assisting in the prevention of perinatal transmission of human T-lymphotropic virus type III/lymphadenopathyassociated virus and acquired immunodeficiency syndrome. MMWR 1985;34:721-31.

6 Minkoff H, Nanda D, Menez R, Fikrig S. Pregnancies resulting in infants with Minkoff $\mathrm{H}$, Nanda D, Menez R, Fikrig S. Pregnancies resulting in infants with
acquired immunodeficiency syndrome or AIDS related complex. Obstet Gynecol 1987;69:285-91.

7 Centers for Disease Control. Revision of the CDC surveillance case definition acquired immunodeficiency syndrome. MMWR 1987;36:1-18s.

8 European Collaborative Study. Mother-to-child transmission of HIV infection. Lancet 1988;ii: 1029-42. 